\title{
Signifikansi: Proses Pencarian Makna Terhadap Teks-teks Agama (Menyibak Pemikiran Nasr Hamid Abu Zaid)
}

\author{
Akhmad Muzakki \\ Penulis adalah Dosen Universitas Islam Negeri (UIN) Malang
}

\section{ABSTRACT}

Naturally, said Gadamer, word belongs to and is taken from reality. Human being looks for appropriate words as form of expression for reality. Ontologically, language created by human being is not only as a means of communication and thinking, but rather it is seen as the manifestation of reality, while they are articulating that language. Therefore, the meaning of a word is in the concept of thought. In the linguistic theory of Saussure, a word is a sign related to signifiant (which gives meaning) and signifie (which is given meaning). The signifiant gives form or expression while signifie concept or meaning. The relationship between the signifiant and the signifie based on the social convention is called signification, or "maghza" in Nasr Hamid's term. In other words, the signification is the effort of giving the meaning to the sign (language). Among the language philosophers, Jacques Derrida, for instance, the last signifie is not always admitted. Derrida said meaning appears due to metaphor exchange and meaning changes when the speakers change. Or, as what Nasr Hamid had expressed, the meaning of the religious texts are not established when the text was made, but rather it is dynamic, relational, and changing depending on the socio-historical background of the readers. 


\section{Prolog}

Munculnya variasi pemahaman dan penafsiran terhadap al-Qur'an sesungguhnya tidak bisa dilepaskan dari adanya proses dialektika antara al-Qur'an (wahyu) dengan kondisi masyarakat Arab. Di satu sisi al-Qur'an dipandang sebagai wahyu yang bersifat transendan dan ahistoris, dan pada sisi yang lain historisitas teks yang menyejarah sangat kental dengan kultur dan budaya Arab. Perpaduan antara dua faktor yang sulit dibingkai secara epistemologis inilah banyak menimbulkan dinamika pemahaman terhadap al-Qur'an.

Mengutip Komaruddin, proses pemahaman, penafsiran dan penerjemahan atas sebuah teks selalu mengasumsikan adanya tiga subyek yang terlibat, yaitu; dunia pengarang, dunia teks, dan dunia pembaca (Komaruddin Hidayat, 1996:17, Lihat juga Alex Sobur, Rosda Karya, 2001: 109).

Tiga subyek ini yang kemudian dikenal dalam dunia hermeneutika dengan "unsur triadik" (the author, text, the readers). Karena itu, pemahaman dan penafsiran terhadap semua teks, termasuk teks-teks al-Qur'an harus melibatkan ketiga unsur di atas. Penafsiran yang hanya menekankan aspek pengarang semata tanpa melibatkan aspek pembaca maka penafsiran tersebut lebih mewakili unsur Ketuhanan-nya dari pada unsur kemanusian-nya. Pada hal al-Qur'an diturunkan Allah melalui Jibril adalah untuk kepentingan kemaslahatan manusia. Indikasi ini dapat dilihat dengan merujuk kepada konsep asbab al-nuzul dan nasikh-mansukh dalam studi al-Qur'an.

Meskipun jarak antara pengarang teks (Tuhan) dan manusia sebagai pembaca demikian jauh namun usaha untuk menghadirkan teks sehingga berada dalam dunia kita menjadi hal yang krusial, agar makna dan pesan moral tersebut bisa direfleksikan seiring dengan kemaslahatan. Dengan demikian, Islam yang diyakini sebagai agama yang sholihun li kulli zamanin wa makanin bukan sekedar ungkapan apologis, melainkan sebuah action dalam realita.

Berdasarkan deskripsi di atas, tulisan ini berusaha menelaah pikiran Nasr Hamid Abu Zaid dalam masalah signifikansi ( $m a g h z a$ ). Yaitu sebuah usaha untuk menemukan makna ketika mendialogkan teks-teks agama (al-Qur'an) dengan konteks sosio-historis pembaca. Proses signifikansi dalam disiplin semiotika menganggap, bahwa teks-teks al-Qur'an merupakan sebagai "tanda" (sign) yang selalu terkait dengan signifiant (penanda) dan signifie (petanda). 


\section{Historisitas Teks}

Perbincangan masalah historitas teks sebenarnya merupakan persoalan klasik yang pernah muncul dalam sejarah peradaban Islam, yaitu antara pemikir Asy'ariyah dengan Mu'tazilah. Kelompok Asy'ariyah berpendapat bahwa firman Tuhan merupakan salah satu dari sifat-sifat Dzat. Dari sini mereka menyatakan, al-Qur'an adalah firman yang azali dan qadim karena ia termasuk sifat Dzat Tuhan. Masih dalam pandangan mereka, bahwa dalam al-Qur'an terdapat dua aspek, pertama, aspek yang bersifat azali dan qadim yaitu firman Tuhan dalam Dzat-Nya sendiri yang mereka istilahkan dengan "firman kedirian yang qadim". $K e d u a$, al-Qur'an yang kita baca merupakan salinan (mimesis) dari firman archaic yang disebut pertama (Nasr Hamid Abu Zaid. 2003: 87)

Argumen di atas berbeda dengan kelompok yang kedua, mereka berpandangan bahwa al-Qur'an itu baru dan makhluk karena ia tidak termasuk dalam sifat-sifat Dzat yang azali. Al-Qur'an adalah firman Allah, sedangkan firman termasuk tindakan, bukan sifat. Dengan demikian, al-Qur'an masuk dalam kategori "sifat-sifat tindakan Tuhan" dan bukan kategori "sifat-sifat Dzat". Kedua kategori ini dibedakannya sebagai berikut, sifat-sifat tindakan merupakan wilayah interaksi antara Tuhan dengan dunia, sementara wilayah sifat-sifat Dzat merupakan wilayah kekhususan eksistensi Tuhan dalam Dzat-Nya sendiri (tidak terkait dengan dunia) (Nasr Hamid Abu Zaid, 2001: 109).

Dalam kajian ini penulis tidak memperdebatkan polemik yang pernah muncul, namun keterangan di atas setidaknya menjadi pengantar bahwa pemikran Mu'tazilah menjadi embrio terhadap pemikiran Nasr mengenai historitas teks alQur'an. Dalam hal ini, Nasr menggunakan paradigma yang digagas Ferdinand de Saussure di mana konsep kalam ia bedakan dengan konsep lughat. Lughat yang dimaksud setara dengan apa yang diistilahkan Saussure dengan langue, yaitu bahasa pada wilayah realitas historis yang dalam hal ini merupakan bagian dari kebudayaan.

Dalam pengertian umum, langue adalah abstraksi dan artikulasi bahasa pada tingkat sosial budaya, sedangkan parole merupakan ekspresi bahasa pada tingkat individu. Langue adalah cabang linguistik yang menaruh perhatian pada tanda bahasa, atau ada pula yang menyebutnya sebagai code bahasa. Termasuk dalam tanda bahasa adalah apa yang oleh para linguis disebut fonem, yaitu satuan 
bunyi terkecil yang dapat membedakan arti. Selain itu, termasuk dalam tanda bahasa juga apa yang disebut dengan morfem, yaitu satuan bentuk bahasa terkecil yang mempunyai makna relatif stabil dan tidak dapat dibagi atas bagian bermakna yang lebih kecil.

Ada perbedaan substansial antara langue dan parole, di antaranya, pertama, langue mempunyai obyek studi berupa tanda atau kode, sementara parole adalah living speech, yaitu bahasa yang hidup, atau bahasa sebagaimana terlihat dalam penggunaannya. Kedua, langue bersifat kolektif dan pemakaiannya tidak disadari oleh pengguna bahasa, sementara parole lebih memperhatikan faktor pribadi pengguna bahasa. Ketiga, unit dasar langue adalah kata, sementar unit dasar parole adalah kalimat. Keempat, langue bersifat sinkronik, dalam arti tanda itu dianggap baku sehingga mudah disusun sebagai sistem, sementara parole boleh dianggap bersifat diakronik, dalam arti sangat terikat oleh dimensi waktu saat terjadi proses pembicaraan (Alex Sobur, 2003: 50-51).

Dalam pandangan Sauusre, mengutip Alex, langue bukanlah kegiatan penutur, ia merupakan produk yang direkam individu secara pasif. Sedangkan parole adalah suatu tindakan individual dari kemauan dan kecerdasannya. Langue adalah suatu kumpulan dari peristiwa-peristiwa, atau bagian sosial dari langage, ia berada di luar individu yang secara mandiri tidak mungkin menciptakan maupun mengubahnya. Langue semacam hasil kontrak di masa lalu di antara para pengguna atau masyarakat bahasa (Alex Sobur, 2003:113).

Kajian terhadap teks-teks al-Qur' an Nasr membuat perbedaan yang tegas antara konsep kalam (yang ahistoris) dengan lughat (historis). Dalam hal ini, ia mengikuti kerangka berpikir Sauusure di mana obyek studi linguistiknya menitikberatkan pada bahasa sebagai prose langue. Karena ia menaruh perhatian pada tanda-tanda bahasa sebagai fakta sosial. Dalam analisis Nasr, karena tandatanda bahasa tidak mengarah pada realitas eksternal-obyektif secara langsung, tetapi mengacu pada konsep dan gambaran mental yang berdiam dalam kesadaran masyarakat, maka ini berarti bahwa bahasa barada dalam inti kebudayaan (sekalipun terjewantah dalam berbagai manifestasi). Dari sini para ahli semiotika mengatakan bahwa kebudayaan adalah ekspresi dari berbagai sistem tanda yang inti pusatnya adalah sistem tanda bahasa (Abu Zaid, 2001).

Jadi, teks-teks agama tidak terpisah dari struktur budaya tempat ia terbentuk. Sumber teks sama sekali tidak mengesampingkan hakikat 
keberadaannya sebagai teks linguistik dengan segala implikasi kebahasaanya. Teks terkait dengan ruang dan waktu dalam pengertian historis dan sosiologis. Teks tidak berada di luar kategori bahasa sehingga tidak memiliki kaitan apapun dengan manusia (Nasr Abu Zaid, 2001: 112). Jika berinteraksi dengan teks agama ini bertolak dari keberadaannya sebagai linguistik, maka ini tidak berarti mengabaikan watak tekstualitasnya yang spesifik. Sebab karakter tekstualitas al-Qur'an didasarkan pada realitas-realitas kemanusiaan yang provan, yang bersifat sosiologis, kultural, dan kebahasaan. Keberadaan firman Tuhan yang kudus baru menjadi perhatian hanya pada momen di mana "kalam tersebut diposisikan secara manusiawi", yaitu ketika Muhammad mengujarakannya dalam bahasa Arab.(Nars Abu Zaid, 2001: 118) Logika ini yang dimaksud Nasr Hamid dengan istilah "historisitas teks", meski seringkali argumen ini bertentangan dengan mayoritas ulama. Untuk itu, kiranya perlu membedakan, baik secara ontologis maupun epistemologis antara pengertian "sejarah teks" dengan unsur "kesejarahan teks".

\section{Memahami Makna}

Memang tidak mudah menjawab pertanyaan, apa makna itu? Upaya memahami makna, sesungguhnya merupakan salah satu masalah filsafat yang tertua dalam umur manusia. Menurut De Vito, makna tidak terletak pada katakata, melainkan pada diri manusia (Joseph A. De Vito,1997: 123) Begitu banyaknya orang mengulas makna sehingga makna hampir kehilangan maknanya. Banyak di antara penjelasan tentang makna terlalu kabur dan spekulatif (Alex Sobur, $2003: 255$ )

Untuk dapat memahami tentang makna ada satu teori yang diangkat Ferdinand de Saussure, yaitu yang disebut dengan "tanda linguistik". Dalam konsepnya bahasa dianggap sebagai sistem tanda. Setiap tanda terdiri dari dua unsur, yaitu; (1) signifie (yang diartikan, petanda, konsep/makna), dan (2) signifiant (yang mengartikan, penanda, bunyi bahasa). Dengan kata lain, setiap tanda linguistik terdiri dari unsur bunyi dan unsur makna. Kedua unsur ini adalah unsur dalam-bahasa (intralingual) yang biasa merujuk/mengacu kepada referen yang merupakan unsur luar-bahasa (Abdul Chaer 1995: 29). Misalnya kata buku, tanda ini terdiri dari unsur makna atau yang diartikan, dan unsur bunyi dalam 
wujud fonem (b, u, k, u) yang mengartikan. Kemudian tanda (buku) mengacu kepada satu referen yang berada di luar bahasa. Teori inilah yang kemudian dipinjam Nasr Hamid ketika ia memposisikan teks-teks agama sebagai lughat/ langue dalam proses pencarian makna melalui pola signifikansi.

Kembali kepada persoalan makna teks-teks agama, jika ia merupakan teksteks manusiawi lantaran ia terkait dengan bahasa dan peradaban dalam rentang sejarah tertentu, yaitu masa formatisasi dan produksinya maka teks-teks tersebut merupakan teks-teks historis, dalam pengertian maknanya tidak terlepas dari sistem bahasa-budaya di mana teks dianggap sebagai begian darinya. Dari sudut ini bahasa dan lingkungan kulturalnya merupakan rujukan dan tafsir untuk menemukan maknanya (Nasr Hamid Abu Zaid, 1994: 206). Karena itu, dalam wacana keagamaan disebutkan, bahwa pemahaman terhadap makna teks-teks agama tidak dimapankan pada fase keterbukaan teks. Hal ini lantaran bahasa sebagai acuan otoritatif tafsir dan interpretasi tidak diam, tetapi bergerak dan berkembang seiring dengan sosio-historis pembaca. Sebuah teks tidak turun tanpa sebab-sebab tertentu ( $a$ sbab al-nuzul), atau seperti yang diungkap Francis Bacon, setiap teks mempunyai ruh zamannya. Historisitas teks tidak hanya meliputi ruang dan waktu, melainkan sekaligus ia adalah sebuah teks yang berkaitan erat dengan teks lainnya yang akan menentukan fleksibilitas makna teks itu sendiri (M. Shofan2004: 75).

Berkaitan dengan wacana yang berkembang dalam tradisi hermeneutika, bahwa makna teks itu akan selalu berubah-rubah maka kita dapat mencermati konsep makna yang dikembangkan Nasr. Ia menyatakan sebagai berikut;

Dalam kajian terhadap teks keagamaan makna dapat dibedakan menjadi; 1) makna yang khusus (tarikhi) dan 2) makna yang umun (daim mustamirr). Menurut Nasr, konsep khas dan 'amm adalah dua sisi makna dalam teks. Yang khusus merupakan sisi semantik yang secara langsung mengacu pada realitas kultural-historis untuk memproduksi teks, sementara yang umum merupakan sisi dinamis, dapat berubah seiring dengan setiap pembacaan. Dengan kata lain, perbedaan tersebut merupakan perbedaan antara makna parsial yang temporal dengan makna umum yang universal. Yang partikular dapat berubah melalui interpretasi metaforis menjadi universal (Nasr Abu Zaid, 1994: 209)

Ungkap Nasr selanjutnya, dalam teks-teks agama terdapat tiga level makna; Pertama, level makna yang hanya merupakan bukti historis yang tidak dapat diinterpretasi secara metaforis. Kedua, level makna yang dapat diinterpretasi 
secara metaforis. Dan ketiga, level makna yang dapat diperluas atas dasar signifikasi yang dapat disingkap dari konteks kultur-sosial di mana teks-teks tersebut bergerak, sekaligus memproduksi maknanya. (Nasr Abu Zaid, 1994: 210215)

Dalam memahami makna kata memang tidak bisa dipisahkan terjadinya dialektika antara teks dan konteks. Teks tidak lahir dari ruang hampa, tetapi teks pada umumnya merupakan respon terhadap situasi yang dihadapi dalam ruang dan waktu tertentu. Dengan lain ungkapan, teks yang kita baca lahir karena ada konteks atau faktor yang melatarbelakangi. Bila pemahaman hanya terfokus kepada teks semata dengan mengabaikan konteks yang melahirkannya maka kita akan terjebak pada kekaburan bahasa. Dan tidak menutup kemungkinan makna atau pesan yang diperoleh tidak sesuai dengan kehendak dan maksud si pembicara (speaker/author). Karena itu, analisis konteks sangat urgen dalam memahami wahyu, sebab ayat-ayat al-Qur'an tidak akan dapat dimengerti kecuali dengan melihat konteks saat wahyu diturunkan. Makna dari sebuah kata baru dapat dikatakan benar bila kita mengetahui siapa pembicaranya dan siapa pendengarnya. Atas pernyataan ini, ahli wacana apabila menganalisis kata/kalimat terlebih dahulu ia menganalisis konteksnya.

Terkait dengan al-Qur'an, Nasr Hamid Abu Zaid menyatakan, berhubung pembentukan teks mengalami dua proses, yaitu proses turun (tanzil) sampai kepada proses interpretasi $\left(t a{ }^{\prime} w l\right)$ maka menganalisis tingkatan konteks menjadi penting dalam studi al-Qur'an dan linguistik. Pertama, konteks sosio kultural, konteks ini terbatas kepada teks yang bersifat kebahasaan, atau kedudukan teks secara umum. Kedua, konteks pewacanaan atau konteks ekstern, maksudnya suatu teks inhern dengan konteks kultural, sedangkan pada aspek-aspek tertentu keduanya terpisah. Ketiga, konteks intern, dalam konteks ini ada dua aspek yang diperhatikan Nasr, a) segi susunan bagian al-Qur'an (juz), b) segi wacana alQur'an itu sendiri. Keempat, konteks narasi atau linguistik, artinya pemahaman terhadap makna-makna gramatikal. Kelima, konteks pembacaan atau konteks interpretasi, ini dikategorikan sebagai konteks karena al-Qur'an memerlukan penjelasan dalam penyampaiannya kepada manusia (Abu Zaid, 2003: 123-134). 


\section{Signifikansi dalam Pemikiran Nasr}

Makna merupakan apa yang dipahami secara langsung dari teks yang diartikulasikan, muncul dalam struktur bahasa dan dalam konteks kebudayaannya. Menurut Nasr Hamid, perbedaan antara "makna" dan "signifikasi" (maghza) terfokus dalam dua dimensi yang tidak terpisah. Dimensi pertama, makna memiliki ciri historis, ia dapat diperoleh melalui pengetahuan konteks linguistik (internal) dan konteks kultural-sosiologis (eksternal). Sementara signifikasi, meskipun tidak dapat dipisahkan dari makna memiliki corak kontemporer dalam pengertian ia merupakan hasil dari pembacaan masa di luar terbentuknya teks. Dimensi kedua, sebagai konsekuensi dari dimensi pertama bahwa makna memiliki aksentuasi yang relatif stabil, sementara signifikasi memiliki corak yang bergerak seiring dengan perubahan horison pembacaan, meskipun hubungannya dengan makna mengarahkan geraknya (Abu Zaid, $1994: 221$ ).

Signifikasi pada prinsipnya merupakan semiotika tingkat langue. Dalam kerangka ini, Saussure bapak linguistik modern berkebangsaan Prancis menjelaskan, tanda sebagai kesatuan yang tidak dapat dipisahkan dari dua bidang, yaitu ; 1) penanda (signifiant/yang mengartikan), 2) petanda (signifie/yang diartikan), Penanda menjelaskan bentuk atau ekspresi, dan petanda menjelaskan konsep atau makna. Dalam keterkaitan dengan tanda, Saussure menekankan konvensi sosial yang mengatur kombinasi tanda dan maknanya. Relasi antara penanda dan petanda berdasarkan konvensi sosial inilah yang disebut signifikasi, atau maghza dalam istilah Nasr Hamid. Dengan kata lain, signifikasi adalah upaya dalam memberi makna terhadap dunia (John Fiske, 1990: 44).

Relasi ini digambarkan Roland Barthes (pengikut Sauusure) untuk menghasilkan makna yang bertingkat, yaitu makna konotasi dan denotasi. Konotasi adalah istilah yang digunakan untuk menunjukkan signifiksi tahap kedua. Konotasi mempunyai makna yang subyektif, atau paling tidak intersubyektif. Denotasi adalah apa yang digambarkan tanda terhadap sebuah obyek, sedangankan konotasi adalah bagaimana menggambarkannya (John Fiske, 1990: 44). Pada signifikasi tahap kedua yang berhubungan dengan isi, tanda bekerja melalui mitos. Mitos adalah bagaimana kebudayaan menjelaskan atau memahami beberapa aspek tentang realitas, atau gejala alam. Dalam pandangan Umar, mitos tidak dibentuk melalui penyelidikan, tetapi melalui anggapan berdasarkan observasi kasar yang 
digeneralisasikan. Karena itu, ia banyak hidup dalam masyarakat (Umar Junus, 1988: 74).

Semiotika struktural yang dikembangkan Saussure yang mengandalkan pada kestabilan tanda, kode dan makna agak bertentangan dengan semiotika yang dikembangkan Derrida. Bila pada semiotika konvensional yang ditekankan adalah proses signifikasi, yaitu memfungsikan tanda sebagai refleksi dari kode-kode sosial yang telah mapan, maka dalam semiotika post-strukturalisme yang ditekankan adalah proses significance, yaitu sebuah proses penciptaan kreatif tanda dan kode-kode yang tanpa batas dan tak terbatas (Yasraf Amir Piliang, 2001: 310).

Teori dekonstruksi menolak pandangan bahwa bahasa telah memiliki makna yang pasti, tetapi teori ini melacak unsur-unsur aporia, yaitu berupa makna paradoksal dan kontradiktif (Burhan Nurgiyantoro, 1995: 58-65).

Hemat penulis, Signifikasi (maghza) yang dimaksud Nasr adalah makna teks selalu bergerak seiring dengan konteks budaya dan sosio-historis pembaca. Pendapat ini tidak berbeda dengan teori semiotika dekonstruksi yang digagas Derrida, bahwa tanda atau teks tidak memiliki rujukan makna final dan selalu berproses. Di kalangan filsuf yang mempunyai minat pada bahasa, misalnya Jacques Derrida, petanda terakhir tidak selalu diakui. Bahasa menurut Derrida, adalah metafora yang tidak mempunyai rujukan final. Makna (petanda terakhir) muncul karena pertukaran metafora, dan makna akan berubah ketika para pelakunya juga berubah. Makna, dengan lain kata, selalu bersifat dinamis, relasional dan rujukannya bersifat tak terbatas (St. Sunardi 1996: 76).

\section{Kesimpulan}

Dalam pandangan Nasr Hamid, al-Qur'an merupakan teks-teks linguistik yang mesti diperlakukan sebagaimana layaknya teks-teks lain dalam peradaban. Dalam keterkaitan dengan bahasa sebagai sistem tanda, signifikasi adalah sebuah upaya untuk memberi makna terhadap tanda tersebut. Teks-teks agama, dalam pandangan Nasr, sebagai tanda yang tidak memiliki makna pasti, selalu bergerak sesuai dengan konteks pembacaan. Atau, dengan kata lain, makna teks-teks agama selalu dinamis dan relasional karena bahasa sebagai acuan otoritatif tafsir dan interpretasi tidak diam, tetapi bergerak dan berkembang seiring dengan kebudayaan 
dan realitas. Bahasa adalah metafora yang tidak mempunyai rujukan final. Makna muncul karena pertukaran metafora, dan makna akan berubah ketika para pelakunya juga berubah.

\section{Bibliography}

Abdul Chaer, Pengantar Semantik Bahasa Indonesia (Jakarta: Rineka Cipta, 1995)

Alex Sobur, Analisis Teks Media: Suatu Pengantar Untuk Analisis Wacana, Analisis Semiotik, dan Analisis Framing (Bandung: Rosda Karya, 2001)

- Semiotika Komunikasi (Bandung: PT Remaja Rosdakarya, 2003)

Burhan Nurgiyantoro, Teori Pengkajian Fiksi (Yogyakarta: UGM Press, 1995)

John Fiske, Introduction to Communication Studies (London : Methuen, 1990)

Joseph A. De Vito, Komunikasi Antar Manusia, ter. Agus Maulana (Jakarta: Professional Books, 1997)

Komaruddin Hidayat, Memahami Bahasa Agama; Sebuah kajian Hermeneutik (Jakarta: Paramadina, 1996)

Mudji Rahardjo, "Ferdinand de Saussure: Bapak Linguistik Modern dan Pelopor Strukturalisme," dalam Lingua, Jurnal Ilmu Bahasa dan Sastra, UN Malang, Vol. 1/No. 1/Sep. 2003.

M. Shofan, "Urgensi Pembacaan Ulang Terhadap al-Qur'an: Menakar Kembali Kebenaran Agama," dalam Kembali ke al-Qur'ân Menafsir Makna Zaman, ed. M. Hilmi Faiq (Malang: UMM Press, 2004)

Nasr Hamid Abu Zaid, Teks Otoritas Kebenaran, ter. Sunarwoto Dema (Yogyakarta: LkiS,2003)

—_ Naqd al-Khitab al-Diniy (Kairo: Jumhuriyah Mishr al-'Arabiyah, 1994)

St. Sunardi, "Membaca Qur'an Bersama Muhammed Arkoun," dalam Tradisi, Kemodernan dan Metamodernisme: Memperbincangkan Pemikiran Muhammed Arkoun, ed. Johan Hendrik Meuleman (yogyakarta: LkiS, 1996) 
Umar Junus, Karya Sebagai Sumber Makna: Pengantar Strukturalisme (Kuala Lumpur: Dewan Bahasa dan Pusat Kementreian Pendidikan Malaysia, 1988)

Yasraf Amir Piliang, Sebuah Dunia Yang Menakutkan: Mesin-Mesin Kekerasan dalam Jagat Raya Chaos (Bandung: Mizan, 2001) 